\title{
E-Leadership: The Implication of Digital Transformation for Leadership in Organizations in Africa
}

\begin{abstract}
FETNANI CECILIA
ABSTRACT

The paper discusses electronic leadership (e-leadership) competencies that would ensure organizational competitiveness in the digital transformation of an organisation or a unit of an organisation. Like any other large-scale transformation of a business that has high failure rates, digital transformation can fail and it is failing in organisations in Africa; making them bankrupt requiring business rescue or taking them completely out of business. Digital transformation is considered as the process of using digital technologies (integrating cyber-physical systems (CPS) i.e., (intelligent network systems) and business processes) to create and improve production, sustain customer experiences; thus, the use of digital technologies to integrate business process, office automation, industrial process and factory automation to transform business. It is therefore argued that most African organizations are currently faced with the critical challenge of determining the preconvergence and convergence of technologies, their alignment with strategy and their integration with business processes and systems to build digital business infrastructure for competitiveness. The concept of enactment of technology-in-practice derived from Adaptive Structuration Theory was used as a lens through which to understand and interpret the implications of the digital transformation on leadership competencies to derive e-leadership profile to lead African businesses in the digital age. As such the objective of this paper is to determine the competencies of e-leadership to lead digital transformation agenda of an organization in a highly and digitally competitive marketplace. It is a qualitative study, using an interpretative paradigm in a case study methodology where semistructured interviews were used to collect data from each unit of analysis representing specific South African based businesses. The selected Cases in South African were extensively investigated. The enactment of e-leadership derived from AST is proposed to lead digital transformation. The implication is that the deployment of e-leadership in an organization has a potential to yield benefits such as the creation of higher organisational flexibility, empowerment of staff and strategic/competitive advantages for the organization. This paper proposes that having effective eleaders in an organisation would lead to adequate appropriation of digital technologies to digitally transform an organisation.
\end{abstract}

Keywords: E-leadership; Adaptive Structuration Theory; cyber-physical systems; internet of things; digital transformation.

\section{INTRODUCTION}

Drawing from [1], it can be argued that in the last few years due to rapid technological developments and innovations in manufacturing and business processes, global industrial and business landscape has radically changed. Thus, the world has entered into the 4th Industrial Revolution (4IR) which has compelled organisations to digitally transform the way their products and services are designed, produced and marketed. The problem which the latter imposes on organisations and in particular, in Africa, is the competencies of current and future leadership to digitally transform current organisations successfully. Agreeably with [2], digital transformation is defined in this paper as the use of digital technologies in a process to create new and/or modify existing - business processes, culture, and customer experiences to meet changing business and market requirements. Thus, reinventing an organisation or a unit of an organisation in the digital age is digital transformation. 
However, the impact of digital transformation on leadership competencies has not been articulated enough, particularly, as it affects organizations in Africa to become competitive. It is therefore argued in this paper that most African organizations are currently faced with the critical challenge of integrating organisational strategy with business processes, culture, customer experiences and systems to build digital business infrastructure for growth and sustainability [3]. Analysing the work of [4], on digital transformation of a business and why it matters, it is agreeable that a digital business or digitally transformed business is a new business design to take advantage of the integration of digital technologies with business processes, culture, customer experiences to deliver value to customers and stakeholders to drive new revenue and efficiency. This paper also considers the digital transformation as a new chapter in human development, which is driven by the increasing availability and interaction of leadership competencies with a set of extraordinary technologies in driving new business models and business transformation agenda. The latter is an agenda driven from the emerging technologies built on the knowledge and systems of prior industrial revolutions, especially the digital capabilities of the third Industrial Revolution (3IR) [1], [2]. The digital transformation therefore creates new operations, business models, and customer experiences with embedded sociotechnical processes that require different leadership competencies which are different from the leadership of the last three Industrial Revolutions (See Fig. 1).

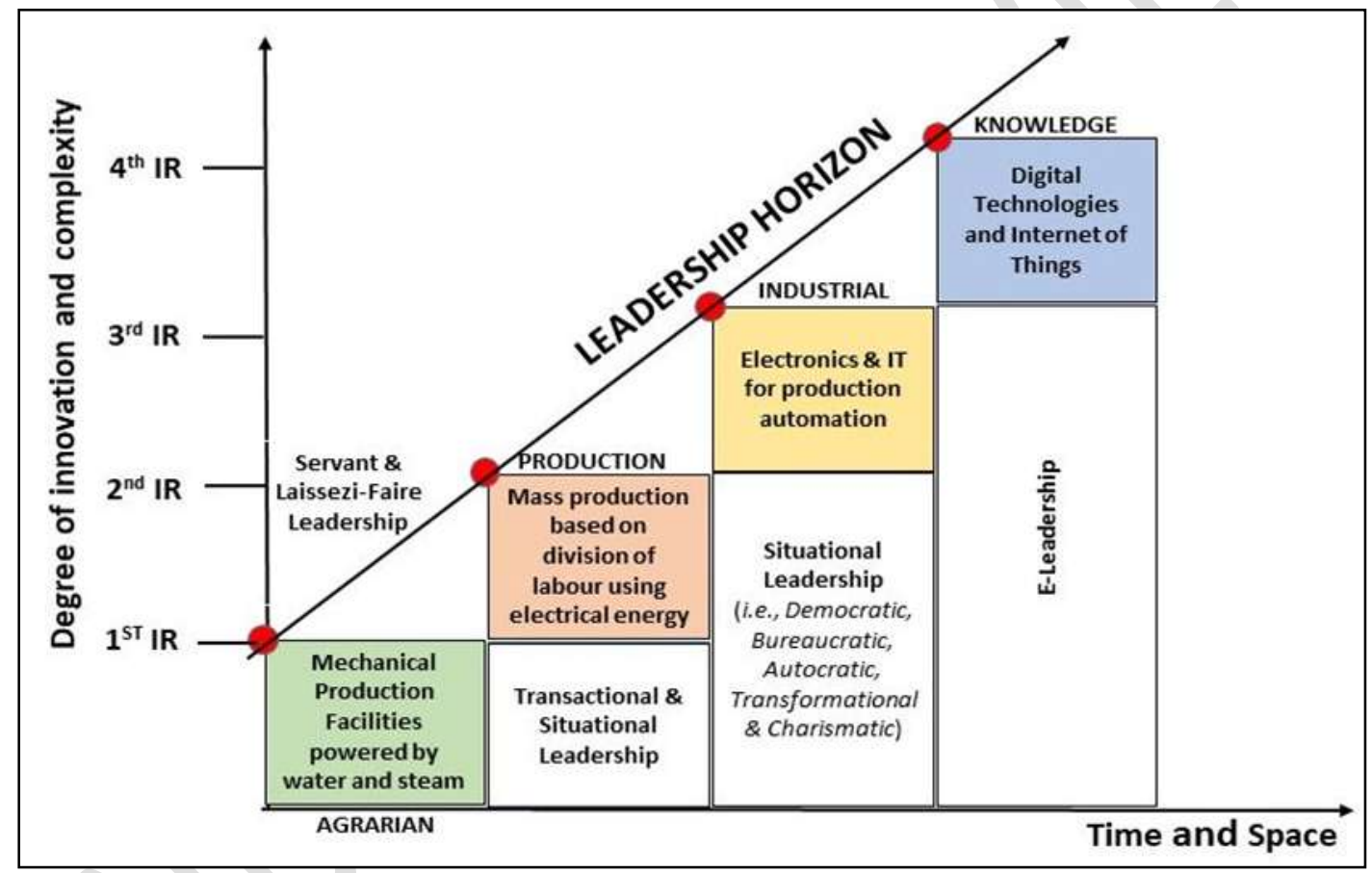

Fig. 1. Leadership horizon

As such, it is therefore argued in this paper that the type of leadership required for digital transformation is an electronic leadership (e-Leadership) which has its peculiar competencies to enable such leaders and their organizations to succeed in digital transformation. Many names have been given to e-leadership some of which are: leading through ICT, virtual leadership, distant leadership, leading virtual teams, tele-leadership, leading from a distance, leading through telecommunications, leading virtual organizations, leading virtual workforces and digital leadership. However, this paper looks at e-leadership from leading through digital technologies. Thus, leading through digital technologies means leading largely by conducting leadership processes in an organisation to enable strategic and business drivers using digital technologies [5]. Therefore, the objective of this paper is to determine the competencies of e-leadership to lead an organisation to digitally transform. The study, therefore, attempted to answer the research questions: (a) what are the leadership competencies required by a leader to lead digital innovation in an organisation? (b) what is required of an organisation to ensure leadership have the space to be innovative to digitally transform 
the organisation? and (c) how can organisation assess its business environment to determine its readiness for digital transformation?

\section{LITERATURE REVIEW}

\subsection{Leadership and E-Leadership in Context}

Drawing from [6], a good leader is one who develops effective group performance; thus, being decisive and forceful and to plan and think for the group while coordinating, directing and evaluating the group's actions. However, this paper acknowledges other viewpoints of leadership which are equally important in leadership development but in the context of the digital transformation, the preference to draw on the view point of [6]. Fiedler [7], leadership is a problem of wielding influence and power and as such different groups require different types of leadership in relation to relationships by which the leader wields influence and power. The study did acknowledge the various types of leadership styles and leadership theories in terms of terminology, definitions and relevance but did not elaborate on them as the focus of the paper was on the distinguishing characteristics of e-leadership. However, this paper briefly touched on the leadership horizon during the last three industrial revolutions (See Fig. 1).

The First Industrial Revolution (1IR) in 1784 (See Fig. 1) was the era of mechanical production facilities powered water and steam was predominantly servant and laissezi-faire (SLF) leadership. The SLF leadership is where the leader gives up some powers for the good of the subordinates in order to give their subordinates the space to own their work and produce results [7], [8]. The SLF leadership was appropriate during $1 \mathrm{IR}$ because the economy and business were driven by families and communities to satisfied their needs [8]. During the second industrial revolution (2IR) in 1870 of mass production based division of labour using electrical energy, the leadership type was predominantly transactional and situational; thus, an era that needed rational understanding of situations and the appropriate response to them [9], [10]. It was an era of moving from communal based business to transaction business across communities which required decisive instructions, creation of organizational patterns, and the use of formal communication channels [11]. The Third Industrial Revolution (3IR) witnessed a permutation of situational and democratic or bureaucratic or autocratic or transformational or charismatic leadership due to society's and business' quest for electronics and IT to automate production. Therefore, in the digital age, it is arguable that leadership of an organisation will wield influence and power base on how digital technologies are appropriated to drive group performance and value creation for customers. By default, strategic leadership for digital transformation of organizations must become e-leaders to be able to derive the capabilities of digital technologies as they try to manage the expectations of new business model, operations and customer experiences across different geographical locations and industries. Moses [12], technology plays a pivotal role in maintaining control over management and administration of an organization. Drawing from the works of [12], it is arguable that there is urgent need for strategic leadership to be equipped in knowledge and use of digital technologies for their organizations to be competitive through digital transformation. Avolio et al. [13], argued that e-leadership is a change in attitudes, feelings, thinking, behaviour, and/or performance which individuals, groups, and/or organizations are influenced as a social process driven by technology. Thus, drawing from [14], e-leaders make critical difference in organizational performance.

According to Jameson [15] and Avolio [13], Avolio et al. [16], Gurr [17], argued that although eleadership concepts have been developed, their impact on organizational competitiveness in the digital age has been overlooked in the research literature. Agreeing with Jameson [15], e-leadership is vital to the strategic alignment of leadership capabilities to the exponential increase in business digital transformation in every organization. According to Zaccaro and Bader [18], the transformation draws on leaders who conduct many of the processes of leadership largely through digital technologies. In [13], it is further argued that e-leadership in view of rapid digital transformation of businesses and their increasingly global competitiveness, would be routine activity through the use of digital technologies.

\subsection{Digital Transformation and Leadership of Organisations}


The digital transformation was originally initiated in Germany to intensively use the globally available Internet network to extensively automate the exchange of information to match production and business processes [14]. This paper argues that digital transformation is considered to be the process whereby digital technologies (i.e., CPS and IoT) are integrated and used to improve production systems, business models and to sustain customer experiences; thus, it is the process of using digital technologies to integrate business process, office automation, industrial process and factory automation to digitally transform an organisation. Digital transformation has progressed from being a cutting-edge aspiration to a business necessity. Business strategies have become more intertwined with Information Technology (IT) as companies are looking for new ways for transforming their organisational activities, processes, and models to fully benefit from the rapid changes and opportunities which come with enabling technologies. Robotic et al. [19] and Vaidya et al. [20] show that digital transformation aims at revolutionizing business models, operations and customer experiences to improve performance and competitiveness. According to Vaidya et al. [20], the main drivers of digital transformation of manufacturing and business processes into fully digital and intelligent one are "Internet of Things (IoT), Industrial Internet (II), Cloud based manufacturing, smart manufacturing, distributed and collaborative proactive tandem location tracking of vehicle products for warehouse operations and graduation manufacturing system (e.g., synchronization with loT-enabled smart tickets)." Drawing from Erol et al. [21] it is arguable that the digital transformation is to optimize production flow and business processes that lead to greater efficiency among suppliers, producers, and customers and effective relationship between human and machine.

Therefore, digital transformation, requires different sets of leadership and managerial competencies to optimize what it brings. Thus, leadership which is able to establish a new business environment that is capable of collecting and comprehensively analysing, evaluating raw data and producing relevant, concise and comprehensive information from many different sources of production equipment, enterprise and customer-management systems to support real-time decision making [20], [21]. Furthermore, the general characteristics of the digital transformation are drawn from Big Data and Analytics, Autonomous Robots, Simulation, System Integration: (horizontal and vertical system integration), Industrial Internet of Things (IloT), Cyber Security and Cyber Physical Systems (CPS), the Cloud, Additive Manufacturing, and Augmented Reality [14]. These characteristics can be and are integrated to achieve the desired outcomes of digital transformation of the business environment. That is, in order to respond and adapt to market and consumer dynamics, digital technologies have revolutionised the development of industries from mechanical systems to highly automated assembly lines today [21].

Thus, $70 \%$ of the world's economy which is made up of manufacturing, oil and gas, agriculture, mining, transportation and healthcare is being confronted with challenges and issues of the digital transformation such as embedded sociotechnical processes, predictability, flexibility and robustness to unexpected conditions [20], [22]. Given Fig. 1, the touching points of time, innovation and complexity with leadership profile suggest different leadership profiles have emerged over the last 3 phases of the industrial revolution. Hence digital transformation requires a different leadership profile or competencies to take-up these technological innovations accompanied by critical reflection, professional development on the characteristics of digital transformation mentioned above into the leadership and management functions of organizations. It is further argued that these competencies can be studied or understood through the lens of a social theory - Adaptive Structuration Theory (AST) explained in the next section.

\subsection{Theoretical Underpinning: Adaptive Structuration Theory (AST)}

Information systems/technology research have often used social theories as a theoretical framework/lens through which to understand the sociotechnical processes embedded in a socially constructed phenomenon. The study used AST [23], [24] and drew from Orlikowski's Enactment of technology-in-practice [25] as a theoretical lens to understand and interpret e-leadership phenomenon as a social construct. Drawing from Structuration Theory [25-28] and AST [23], [24], it is argued that technology as a social construct of human actions is used to build structures/rules that affect the future actions [29], [30]. Thus, AST attempts to explain human behaviour and actions within the 
context of technology appropriation. As such it can be utilized in organizational and group settings to understand and interpret performance with the use of technology. According to Monteiro and Hanseth [31], enacting technology-in-practices (Fig. 2) derived from AST provides the framework with which to understand the interplay between leadership actions and technology artefacts, in this case, the leadership competency to drive digital transformation of businesses.

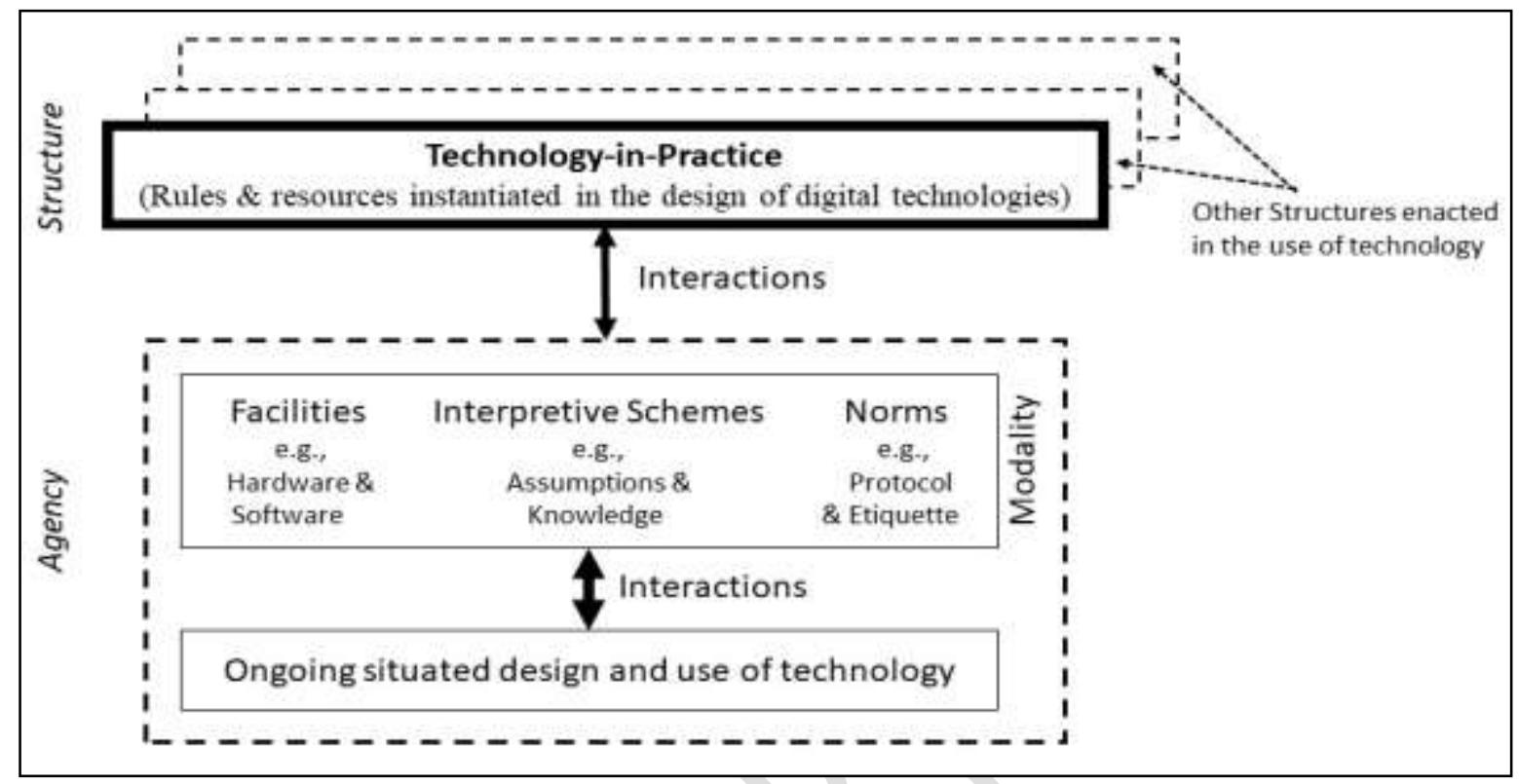

Fig. 2. Enactment of technology-in-practice (Orlikowski, 2000:416)

It is therefore arguable that digital technologies (i.e., integrated loT and CPS infrastructure as material artefact) for a business/organisation to succeed in digital transformation is a leadership action and as such, inherently social. Deducing from the works of [32], [33], digital technologies is a continuous design and redesign by 'human action' and used by 'humans' to accomplish the intended business or digital transformation as prescribed by the leadership of the organisation who have certain competencies. That is, continuous use of digital technologies' rules and resources by users can change the established structure - new business model, processes, and customer experiences - of an organisation to become globally competitive. This was further articulated by [25-28].

\section{METHODOLOGY}

\subsection{Research Approach}

It is evident from the reviewed literature that the impact of digital transformation on leadership of organisation in Africa is a social phenomenon with an embedded sociotechnical processes making it ontologically subjective. As such the study adopted a qualitative approach [34] using an interpretative paradigm in a case study methodology for an in-depth understanding of the phenomenon [35] where semi-structured interviews were used to collect data to discover rather than a confirmation.

\subsection{The Case and Population}

The population included all senior executives from 11 selected African based organizations as units of analysis who are actively involved in digital transformation of their organisations to become locally and globally competitive in the digital age. Each unit of analysis represents a specific African business of an average of 300 employees, geographically dispersed in South Africa in both retail and manufacturing sectors. Each of the 6 units of the 11 units of analysis are in the manufacturing sector and have an average of 3000 customers. The other 5 units of analysis which are in the retail sector 
have an average of 5 million customers across South Africa. The senior executives have extensive senior management experience extending beyond 15 years and have worked in at least 5 different organizations but in the same sector. Some of the executives interviewed are permanent staff or are on 5-year contract or are seconded from a sister organization.

\subsection{Sampling}

A purposive sampling method was used to select 55 senior executives from the population. This sample included one senior executive from each functional area of Finance, Supply Chain \& Logistics, Human Capital, Information Technology, Business Development \& Marketing and Engineering (in the case of manufacturing sector). Informed consent with an invitation to participate in the study was sent via email to each selected senior executive. In the event that this was unsuccessful, convenience sampling was used. The selection from varying levels of tenure ensured a variety of responses from different functional area and levels of experience in order to obtain a well-rounded view of the digital transformation domain.

\subsection{Data Collection}

The study obtained the views of the 55 senior executives by face-to-face interviews using semistructured questions. The interview questions were guided by the gaps in the reviewed literature and the enactment of technology-in-practice framework of AST. The major themes that emerged included social, process and technology factors.

\subsection{Data Analysis}

Drawing from Fowler [36], coding (Table 1) which involved the selection of keywords or phrases that are related to the major themes of social, process and technology factors was used for data organisation and reduction. The main themes are related to enactment of Technology-in Practice of AST, which was used as a lens to understand and interpret the phenomenon.

Table 1. Summary of coding scheme

\begin{tabular}{lll}
\hline Factors & Code & Description of competencies \\
\hline Technology & $\begin{array}{l}\text { Technical } \\
\text { Infrastructure (to } \\
\text { switch to convergence) }\end{array}$ & $\begin{array}{l}\text { The competency to mobilize, direct and secure good } \\
\text { quality corporate/competition data for the computerized } \\
\text { and production systems to interchange data to ensure } \\
\text { business, IT and externa stakeholders alignment. }\end{array}$ \\
\hline Process & $\begin{array}{l}\text { Functionality (as } \\
\text { alignment) }\end{array}$ & $\begin{array}{l}\text { The competency to lead the design of digital } \\
\text { transformation /solution in line with business functions, } \\
\text { standards / policies, technical / technology, incremental / } \\
\text { piloting / scenarios approach with feasible objectives and } \\
\text { quick, scalable loT \& CPS components into services } \\
\text { more simply. }\end{array}$ \\
& $\begin{array}{l}\text { The competency to lead and execute the integration of } \\
\text { various applications, information, structures and } \\
\text { technologies according to the functionality, policies, } \\
\text { standards, SLAs and guidelines to ensure compliance } \\
\text { and accountability. }\end{array}$ \\
\hline $\begin{array}{ll}\text { Integration capability } \\
\text { (according to } \\
\text { functionality) }\end{array}$ & $\begin{array}{l}\text { The Competency to create innovation and commit to and } \\
\text { to own the digital transformation process }\end{array}$ \\
\hline Social & $\begin{array}{l}\text { Leadership (strategic } \\
\text { thinking and innovation } \\
\text { as pre-convergence) }\end{array}$ & \\
\hline
\end{tabular}

\subsection{Reliability and Validation}

The reliability of this study is drawn from the detailed description of the research processes which offers opportunities for process replication. A piloted interview schedule conducted ensured reliability 
which was further enhanced through the transcribed interview responses and the content analysis ensured improved understanding of the data and the responses in their entirety. Drawing from Clifton et al. [37], the validity of interview data was assessed through the correlation of other responses given by the interviewees and responses which featured in a number of places in the analysis. The transcribed interviews of the 55 respondents were subjected to scrutiny to validate the findings. Kemal [38], it can be argued that this systematic methodology adopted in this study also contributed to the validation of the findings.

\section{RESULTS AND DISCUSSION}

\subsection{Factors Influencing E-Leadership Competencies}

In general, although not exhaustive, drawing from Bowker and Star [39], Holmström and Robey [40], the basic factors influencing good leadership can be argued and described in the context of this paper as:

- Influence: lead by example, visionary, and adapt to bring about necessary change;

- Improvement: continuous personal development, relationship development and abreast with technology to drive necessary change;

- Inspiration: decisive in decision making, ownership of the consequences of decisions and to coach direct reports;

- Integrity: knowledgeable of team, to be informed and to be trusted.

However, the findings show that the key factors influencing e-leadership competencies are:

1) Re-structuring abilities: does not see silos i.e., all functions of the organisation are to be integrated to remove sub-optimization of processes;

2) Creativity \& innovation abilities: creator and supporter of innovation function to drive digital transformation and focuses on delivering customized services to individuals and/or stakeholders.

3) Technology savvy: leads the agenda of re-skilling of current staff on the characteristics and impact of loT and CPS and digital transformation of business functions.

4) Ability to create opportunities: creates opportunities to utilize and demonstrate analytical, problem-solving skills and know-how; recognizes tangible results when they are obtained; provides the autonomy in expressing ideas and putting them into action; and challenge and stimulate work.

\subsection{Enactment of E-Leadership in Practice}

The findings also show that the rules and resources to be instantiated in the design and use of technology (IOT and CPS) to create new or reinvent current business models are within the competency of the e-leader. According to Orlikowski [24], it can be inferred that the characteristics of digital technologies (IOT and CPS) infrastructure which drives the digital business or organisation, play a crucial role in empowering and strengthening the dominating trends of business transformation or the digital transformation agenda. Thus, the redesigning or reinventing of the relationship between the digital technologies and digital transformation (enacting e-leadership-in-practice - Fig. 3 ) is in the competency of the e-Leader - an independent, analytic, fast and disciplined thinker. Furthermore, the findings also indicate that the e-leader must be a decisive and a relationship builder who seeks to get things done by the "book" and quickly. Thus by prescribing such a competency, the e-leader is able to "freeze" [41] the transformation agenda such that the digital transformation process is irreversible, making the process ongoing to achieve intended or desire results (Fig. 3). This means that the actions of the e-leader to digitally transform the organisation using ongoing innovation of digital technologies becomes "black-boxed" i.e., no longer controversial [41]. The findings also established that the eleader must have a general technology orientation and creative competency as a link between employees and the digitalization agenda for the digital business or organisation. Digital transformation which has a peculiar characteristics alluded to earlier in the literature review, is a type of an 
information and technology infrastructure making it a systemic technology [41], which therefore regulates communicative behaviour, roles and standards. As such the e-leader ought to be selfconfident, results oriented and base his/her decisions on facts and details to drive ongoing digital transformation and continuous appropriation of digital technologies for the digital transformation.

\subsection{The Digital Transformation as Ongoing Situated Design and Use of Digital Technologies}

The respondents offered their views on how e-leadership can be formalized as a new leadership profile/style for digital transformation of an organisation by implementing a framework that can predict the illustrated e-leadership competencies above. This will include the incorporation of a structured and systematic instrument using digital technologies with the right policies, standards and procedure to entrench e-leadership competencies across the organization. It was evident from the findings that new digital technologies (integrated CPS and IoT) infrastructure is needed for digital transformation and digital business to succeed, particularly, where management, training and administrative functions are defined for digital business. Thus the ongoing appropriation of digital technologies to entrench the characteristics of digital transformation in the organisation is based on the digital technologies' infrastructure as derived from the attributes of the technical design and functionality needed to transport digital content (i.e., convergence); the authority to execute or implement the technology artefact (embedded rules and resources) and the attitude and behaviour of employees to embrace the technology artefact and comply with policies and standards emanating from digital transformation enterprise. The emerged findings from the analysis of data informed the proposed general framework (see Fig. 3) which is a revised framework of the theoretical framework of Fig. 2 and represents eleadership-in-practice for digital transformation. Fig. 3 illustrates the e-leadership competencies for digital transformation where the integration of IoT and CPS strategy of an organisation is aligned to AST.

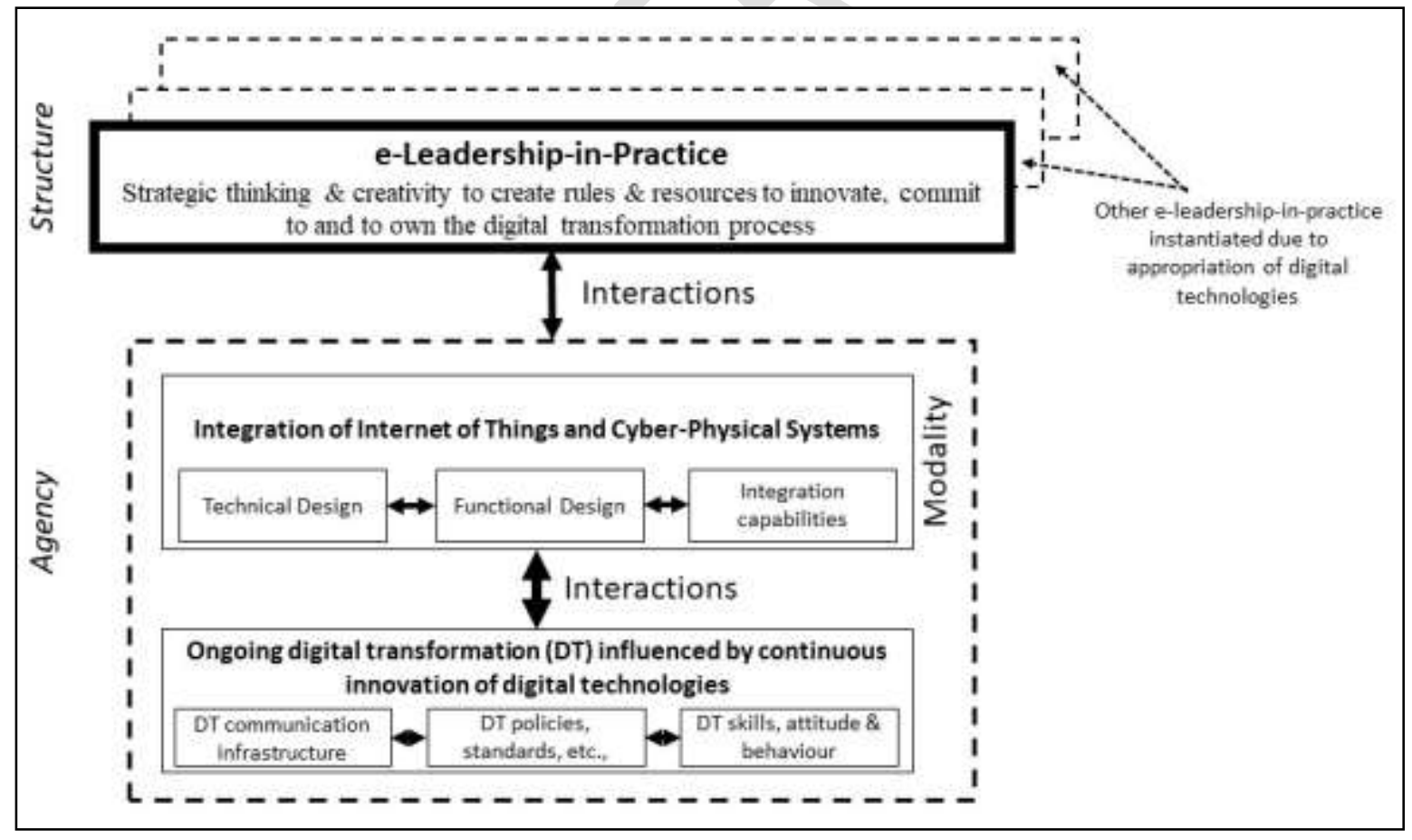

Fig. 3. Enacting e-leadership-in-practice

\section{CONCLUSION AND RECOMMENDATION}

\subsection{Introduction}


This paper was set out to understand and interpret the impact of the digital economy leadership of organizations in Africa. The impact was determined through the theoretical lens of enactment of Technology-in-Practices of dimensions of DoT derived from AST. Therefore, the paper presents another way to understand the e-Leadership competency required by organizations in African to compete in the digital economy. It can be argued that there is a limited study undertaken in the area of the digital economy and e-leadership and hence current literature does not present results similar to what this paper is proposing. However, the reviewed literature provided the background to current understanding of leadership and e-leadership. Furthermore, the themes were based on the gap in the reviewed literature and how the digital economy would impact on leadership in Africa and it's organisations including business, government and academic institutions. Although, the main objective of the study was to understand and interpret the competencies of e-Leadership, the competencies and the characteristics of the digital economy contributed to the development of a general framework to guide the identification, recruitment and appointment of e-Leaders for organizations in the digital economy. To achieve the objective, three research questions:

a) What are the leadership competencies required by a leader to lead innovation in the digital economy?

b) What is required of an organisation to ensure leadership have the space to be innovative to digitally transform the organisation? and

c) How can organisation assess its business environment to determine its readiness for digital transformation? had to be answered to reveal the factors impacting on leadership competencies to enactment e-leadership in practice.

\subsection{Summary of Findings}

The findings of this study support the argument that a new leadership as illustrated in Fig. 1 and Fig. 2 is required by organisations in Africa to deal with the impact of the digital economy on their competitiveness. E-leadership is achieved when the social, technology and process factors influencing leadership in the digital economy come together. The study is an affirmation that eLeadership is a social construct, as long as people continuously influence the integration of loT and CPS to achieve different results due to the demands of the digital economy. The characteristics of the digital economy reveal that the competencies of e-leadership will enable the creation of right rules and adequate resources to instantiate digital transformation projects to sustain and grow an organization in the digital economy. Thus, all or the combination of these competencies (Independent, fast and disciplined thinker, self-confident and results oriented, gets things done by the book and quickly, decisive and relationship builder, General technology orientation and creativity, and Base decisions on facts and details) constitute the social factors influencing the leader to establish and interact with the digital economy's technical infrastructure, the digital economy policies, standards, procedures, checklists and to train and develop the digital economy skills, attitude and behaviour of employees. These interactions are constantly modulated or mediated (see Fig. 3) by the design and redesign of the technology artefacts; thus, continuous integration of loT and CPS.

\subsection{Implications and Recommendations}

The outcome of the implications of digital transformation on leadership is the creation of e-leadership profile i.e., to sustain and grow digital organisation, particularly in Africa to become globally competitive. Thus, digital transformation requires e-leadership to be able to:

a) Assess current business environment to determine its readiness for the digital transformation;

b) Have an insight into how the organisation must reap the benefits of digital technologies with the view to design business model, formulate new organisational policies and strategies;

c) Establish predictors to track and develop current leaders and emerging e-leaders for digital transformation of business;

d) Establish and improve existing application of telecommunication technologies due to its ability to bridge time and distance e.g., machine to machine $(\mathrm{m} 2 \mathrm{~m})$ protocols; 
e) Educate, train and re-skill new and current workforce on the implications of digital technologies and digital transformation;

\subsection{Limitations and Future Study}

Although this study was conducted with a rigorous process of analysis, the application of the findings must be well-thought-through due to some limitations of the study. The study used data that were collected from 11 organizations based and operating in Africa from Cape Town. Therefore, the findings cannot be interpreted for context outside Africa and in particular outside the manufacturing of engineering products, clothing \& textile and wholesale \& retail sectors. It is suggested that future study is done in other Industries and perhaps outside Africa to validate and verify these findings. It is advisable that the future study be done using quantitative techniques for further validation of the current findings in other Industries or sectors. Thus, reliability and higher validity are associated with quantitative survey research than qualitative interviews and would improve the generalizability of the data. Furthermore, this study was conducted among senior executives and as such future studies could include middle-level management and operational staff as their skills, attitude and behaviour can influence the e-leadership in practice to digitally transform business/organisation. It should also be noted that the sampled organizations are not completely digitally transformed and were working on digital transformation strategies to survive in the digital economy. Therefore, the findings for organizations that already engaging in formal digital transformation strategy might give different competencies. Arguably, future studies could compare the e-leadership competencies that emerge out of such organizations with those organizations which do not have the digital economy strategy. Given the originality of this study and the limited use of enactment of Technologies-in-practice as a theoretical lens in a study focusing on leadership in the digital economy, further studies should explore whether these competencies are in fact specific to e-Leadership or if there are overlapping competencies between different organizations and leadership profiles. Further studies could be conducted using same methodology for Institutions of Higher Learning in Africa. The view is that the same instrument might generate similar or different results for a different context.

\section{REFERENCES}

Setiawan, Adib Rifqi. (2017, February 24). Penerapan Pendekatan Saintifik untuk Melatihkan Literasi Saintifik dalam Domain Kompetensi pada Topik Gerak Lurus di Sekolah Menengah Pertama. Undergraduate Thesis. Bandung: Universitas Pendidikan Indonesia. URL: http://repository.upi.edu/29074/

Setiawan, Adib Rifqi. (2020, April 21). Lembar Kegiatan Literasi Saintifik untuk Pembelajaran Jarak Jauh Topik Penyakit Coronavirus 2019 (COVID-19). Edukatif: Jurnal Ilmu Pendidikan, 02(01): 28-37. DOI: https://doi.org/10.31004/edukatif.v2i1.80

Setiawan, Adib Rifqi. (2020, March 01). Pendidikan Literasi Finansial Melalui Pembelajaran Fiqh Mu'āmalāt Berbasis Kitab Kuning. Nazhruna: Jurnal Pendidikan Islam, 03(01): 138159. DOI: https://dx.doi.org/10.31538/nzh.v3i1.522

Setiawan, Adib Rifqi. (2020, January 24). Pembelajaran Tematik Berorientasi Literasi Saintifik. Jurnal Basicedu: Journal of Elementary Education, 04(01): 71-80. URL: https://jbasic.org/index.php/basicedu/article/view/298

Setiawan, Adib Rifqi. (2019, December 30). Instrumen Penilaian Pembelajaran Fiqh Mu'āmalāt Berorientasi Literasi Finansial. Eklektik: Jurnal Pendidikan Ekonomi dan Kewirausahaan, 02(02): 258-272. DOI: http://dx.doi.org/10.24014/ekl.v2i2.8117

Setiawan, Adib Rifqi. (2019, December 20). Literasi Saintifik Berdasarkan Kecerdasan Majemuk dan Motivasi Belajar. Media Penelitian Pendidikan: Jurnal Penelitian dalam Bidang Pendidikan dan Pengajaran, 13(02): 126-137. DOI: http://dx.doi.org/10.26877/mpp.v13i2.4913 
Setiawan, Adib Rifqi; Puspaningrum, Mita; \& Umam, Khoirul. (2019, December 06). Pembelajaran Fiqh Mu'āmalāt Berorientasi Literasi Finansial. Tarbawy: Indonesian Journal of Islamic Education, 06(02): 187-102. URL:

https://ejournal.upi.edu/index.php/tarbawy/article/view/20887

Setiawan, Adib Rifqi. (2019, October 02). Efektivitas Pembelajaran Biologi Berorientasi Literasi Saintifik. Thabiea : Journal of Natural Science Teaching, 02 (02): 83-94. DOI: http://dx.doi.org/10.21043/thabiea.v2i2.5345

Setiawan, Adib Rifqi. (2019, September 30). Instrumen Penilaian untuk Pembelajaran Ekologi Berorientasi Literasi Saintifik. Assimilation: Indonesian Journal of Biology Education, 02(02): 42-46. DOI: https://dx.doi.org/10.17509/aijbe.v2i2.19250

Setiawan, Adib Rifqi; Mufassaroh, Arij Zulfi. (2019, June 28). Menyusun Soal Literasi Saintifik untuk Pembelajaran Biologi Topik Plantae dan Animalia. BIOSFER: Jurnal Biologi dan Pendidikan Biologi, 04(01): 33-40. URL: http://dx.doi.org/10.23969/biosfer.v4i1.1484

Setiawan, Adib Rifqi. (2019, June 26). Peningkatan Literasi Saintifik melalui Pembelajaran Biologi Menggunakan Pendekatan Saintifik. Journal of Biology Education, 02(01): 223-235. URL: http://journal.stainkudus.ac.id/index.php/jbe/article/view/5278

Setiawan, Adib Rifqi; Utari, Setiya; Nugraha, Muhamad Gina. (2017, September 22). Mengonstruksi Rancangan Soal Domain Kompetensi Literasi Saintifik Siswa SMP Kelas VIII pada Topik Gerak Lurus. Wahana Pendidikan Fisika, 02(02): 44-48. URL: https://ejournal.upi.edu/index.php/WPF/article/view/8277/0

Setiawan, Adib Rifqi. (2020, April 20). Menyusun Instrumen Penilaian untuk Pembelajaran Ekologi Berorientasi Literasi Saintifik. Prosiding Seminar Nasional dan Workshop BiologiIPA dan Pembelajaran Ke-4 (SnoWBel IV): 241-9. ISBN : 978-602-470-170-3 \& eISBN : 978-602-470-171-0.

Setiawan, Adib Rifqi. (2020, February 18). Menyusun Instrumen Penilaian untuk Pembelajaran Topik Lingkungan Berorientasi Literasi Saintifik. Prosiding Seminar Nasional Fisika (SiNaFi) 2019: 15-21. URL: http://proceedings.upi.edu/index.php/sinafi/article/view/563

Setiawan, Adib Rifqi. (2020, January 17). Penggunaan Mabadi 'Asyroh dalam Pembelajaran Biologi untuk Meningkatkan Motivasi dan Hasil Belajar. Prosiding Seminar Nasional Biologi 2019 Inovasi Penelitian dan Pembelajaran Biologi III (IP2B III): 158-164. URL: http://semnasbiologi.conference.unesa.ac.id/ocs/index.php/semnasbio/IP2BIII/paper/v iewFile/11/21

Setiawan, Adib Rifqi. (2020, January 17). Upaya Meningkatkan Motivasi Belajar dalam Pembelajaran Ilmu Pengetahuan Alam (IPA) Melalui Bacaan Populer. Prosiding Seminar Nasional Biologi 2019 Inovasi Penelitian dan Pembelajaran Biologi III (IP2B III): 154-157. URL:

http://semnasbiologi.conference.unesa.ac.id/ocs/index.php/semnasbio/IP2BIII/paper/v iewFile/5/51

Setiawan, Adib Rifqi. (2020, January 17). Penerapan Pendekatan Saintifik dalam Pembelajaran Biologi sebagai Upaya Melatih Literasi Saintifik. Prosiding Seminar Nasional Biologi 2019 Inovasi Penelitian dan Pembelajaran Biologi III (IP2B III): 140-145. URL: http://semnasbiologi.conference.unesa.ac.id/ocs/index.php/semnasbio/IP2BIII/paper/v iewFile/6/19 
Setiawan, Adib Rifqi. (2019, October 14). Penyusunan Program Pembelajaran Biologi Berorientasi Literasi Saintifik. Seminar Nasional Sains \& Entrepreneurship VI (SNSE VI): 255-18. URL: http://conference.upgris.ac.id/index.php/snse/article/view/255

Setiawan, Adib Rifqi. (2019, May 07). Penerapan Pendekatan Saintifik untuk Melatih Literasi Saintifik dalam Domain Kompetensi pada Topik Gerak Lurus di Sekolah Menengah Pertama. Prosiding Seminar Nasional Fisika (SiNaFi) 2018: 7-13. URL: http://proceedings.upi.edu/index.php/sinafi/article/view/355

Setiawan, Adib Rifqi. (2019, November 23). Profil Literasi Saintifik Berdasarkan Kecerdasan Majemuk dan Motivasi Belajar. Seminar Nasional Fisika V (SiNaFi 5.0), Universitas Pendidikan Indonesia (UPI). DOI: https://dx.doi.org/10.35542/osf.io/m7n95

Setiawan, Adib Rifqi. (2019, November 23). Menyusun Instrumen Penilaian untuk Pembelajaran Topik Lingkungan Berorientasi Literasi Saintifik. Seminar Nasional Fisika V (SiNaFi 5.0), Universitas Pendidikan Indonesia (UPI). DOI: https://dx.doi.org/10.35542/osf.io/sc6d2

Setiawan, Adib Rifqi. (2019, November 23). Analisis Keabsahan dan Keandalan Science Motivation Questionnaire II (SMQ II) Versi Bahasa Indonesia. Seminar Nasional Fisika V (SiNaFi 5.0), Universitas Pendidikan Indonesia (UPI). DOI: https://doi.org/10.31237/osf.io/6zeph

Setiawan, Adib Rifqi. (2019, October 05). Menyusun Instrumen Penilaian untuk Pembelajaran Ekologi Berorientasi Literasi Saintifik. Seminar Nasional \& Workshop Biologi, IPA, dan Pembelajarannya ke-4 (SnoWBel IV), Universitas Negeri Malang (UM). DOI: https://dx.doi.org/10.13140/RG.2.2.21931.39206

Setiawan, Adib Rifqi. (2019, August 21). Penyusunan Program Pembelajaran Biologi Berorientasi Literasi Saintifik. Seminar Nasional Sains \& Entrepreneurship VI (SNSE VI), Universitas PGRI Semarang (UPGRIS). DOI: https://dx.doi.org/10.13140/RG.2.2.13716.86400

Setiawan, Adib Rifqi. (2019, March 23). Upaya Meningkatkan Motivasi Belajar dalam Pembelajaran Ilmu Pengetahuan Alam (IPA) Melalui Bacaan Populer. Seminar Nasional Biologi 2019 Inovasi Penelitian dan Pembelajaran Biologi III (IP2B III), Universitas Negeri Surabaya (UNESA). DOI: https://dx.doi.org/10.13140/RG.2.2.13087.71847

Setiawan, Adib Rifqi. (2019, March 23). Penerapan Pendekatan Saintifik dalam Pembelajaran Biologi sebagai Upaya Melatih Literasi Saintifik Siswa Sekolah Menengah. Seminar Nasional Biologi 2019 Inovasi Penelitian dan Pembelajaran Biologi III (IP2B III), Universitas Negeri Surabaya (UNESA). DOI: https://dx.doi.org/10.13140/RG.2.2.19798.60484

Setiawan, Adib Rifqi. (2019, March 23). Penggunaan Naḍom Mabādī 'Asyroh dalam Pembelajaran Biologi untuk Meningkatkan Motivasi dan Hasil Belajar. Seminar Nasional Biologi 2019 Inovasi Penelitian dan Pembelajaran Biologi III (IP2B III), Universitas Negeri Surabaya (UNESA). DOI: https://dx.doi.org/10.13140/RG.2.2.33220.37763

Setiawan, Adib Rifqi. (2018, November 24). Penerapan Pendekatan Saintifik untuk Melatih Literasi Saintifik dalam Domain Kompetensi pada Topik Gerak Lurus di Sekolah Menengah Pertama. Seminar Nasional Fisika ke-4 (SiNaFi IV), Universitas Pendidikan Indonesia (UPI). DOI: https://dx.doi.org/10.13140/RG.2.2.23154.04809

Setiawan, Adib Rifqi; Utari, Setiya; Nugraha, Muhamad Gina. (2016, December 17). Mengonstruksi Rancangan Soal Domain Kompetensi Literasi Saintifik Siswa SMP Kelas VIII pada Topik Gerak Lurus. Seminar Nasional Fisika ke-2 (SiNaFi II), Universitas Pendidikan Indonesia (UPI). DOI: https://dx.doi.org/10.13140/RG.2.2.31856.10246/1 
Setiawan, Adib Rifqi. (2020, May 12). Introducing the Indonesian Education System. Thesis Commons. DOI: https://doi.org/10.31237/osf.io/ygt5c

Setiawan, A. R. (2020, May 7). Discovering the Fundamental Problem of Four Methods to Analyze Data. Thesis Commons. DOI: https://doi.org/10.31237/osf.io/h953y

Setiawan, Adib Rifqi. (2020, May 6). Menyibak Makna Karya Fadhilaturrahmi. LIS Scholarship Archive. DOI: https://doi.org/10.31229/osf.io/65y4z

Setiawan, Adib Rifqi. (2020, May 6). Discovering the Meaning of Fadhilaturrahmi's Work. Thesis Commons. DOI: https://doi.org/10.31237/osf.io/krf7z

Feldman, DarHalevy; \& Setiawan, Adib Rifqi. (2020, April 24). Education in Israel. Thesis Commons. DOI: https://doi.org/10.31237/osf.io/62shg

Setiawan, Adib Rifqi. (2020, April 18). Musyāfahah al-Qur'ān Melalui Media Elektronik. Thesis Commons. URL: https://thesiscommons.org/ntjp9/

Setiawan, Adib Rifqi. (2020, April 14). Jalāl al-Dīn 'Abd al-Roḥmān ibn Abī Bakr al-Suyūṭ̂̄. SocArXiv. DOI: https://doi.org/10.31235/osf.io/5zf9v

Setiawan, Adib Rifqi. (2020, April 14). Commodification of the Sexuality in Kim Kardashian's Instagram Posts. SocArXiv. DOI: https://doi.org/10.31235/osf.io/kd6au

Velasufah, Whasfi; \& Setiawan, Adib Rifqi. (2020, April 13). Nilai Pesantren Sebagai Dasar Pendidikan Karakter. Thesis Commons. DOI: https://doi.org/10.31237/osf.io/hq6kz

Setiawan, Adib Rifqi. (2020, April 13). Commodification of the Sexuality in Kim Kardashian's Instagram Posts. Thesis Commons. URL: https://thesiscommons.org/mf7nw/

Setiawan, Adib Rifqi. (2020, April 13). مبادئ اللغة العربية. Thesis Commons. DOI: https://doi.org/10.31237/osf.io/2gvjf

Siayah, Syarofis; \& Setiawan, Adib Rifqi. (2020, April 13). A Brief Explanation of Science Education. EdArXiv. DOI: https://doi.org/10.35542/osf.io/2evn3

Siayah, Syarofis; \& Setiawan, Adib Rifqi. (2020, April 13). A Brief Explanation of Science Education. Thesis Commons. DOI: https://doi.org/10.31237/osf.io/wkvsn

Setiawan, Adib Rifqi; \& Ilmiyah, Surotul. (2020, April 13). Multiple Intelligences Based on Neuroscience. Thesis Commons. DOI: https://doi.org/10.31237/osf.io/e9fyu

Setiawan, Adib Rifqi; \& Ilmiyah, Surotul. (2020, April 13). Kecerdasan Majemuk Berdasarkan Neurosains. EdArXiv. DOI: https://doi.org/10.35542/osf.io/rj2fe

Setiawan, Adib Rifqi. (2020, April 9). Islamic Education in Southeast Asia. EdArXiv. DOI: https://doi.org/10.35542/osf.io/dnjqv

Setiawan, Adib Rifqi. (2020, April 9). Islamic Education in Southeast Asia. Thesis Commons. DOI: https://doi.org/10.31237/osf.io/e794d

Ilmiyah, Surotul; \& Setiawan, Adib Rifqi. (2020, April 7). Students' Worksheet for Distance Learning Based on Scientific Literacy in the Topic Coronavirus Disease 2019 (COVID-19). Thesis Commons. DOI: https://doi.org/10.31237/osf.io/fpg4j 
Ilmiyah, Surotul; \& Setiawan, Adib Rifqi. (2020, April 7). Students' Worksheet for Distance Learning Based on Scientific Literacy in the Topic Coronavirus Disease 2019 (COVID-19).

EdArXiv. DOI: https://doi.org/10.35542/osf.io/wyz5v

Setiawan, Adib Rifqi; \& Ilmiyah, Surotul. (2020, April 7). Lembar Kegiatan Siswa untuk Pembelajaran Jarak Jauh Berdasarkan Literasi Saintifik pada Topik Penyakit Coronavirus 2019 (COVID-19). EdArXiv. DOI: https://doi.org/10.35542/osf.io/h4632

Setiawan, Adib Rifqi. (2020, April 5). The Arrogant One. Thesis Commons. DOI: https://doi.org/10.31237/osf.io/8nmku

Setiawan, Adib Rifqi. (2020, April 4). Grace Natalie Louisa. SocArXiv. DOI: https://doi.org/10.31235/osf.io/zwf6g

Setiawan, Adib Rifqi. (2020, April 4). Grace Natalie Louisa. Thesis Commons. DOI: https://doi.org/10.31237/osf.io/u3mxv

Setiawan, Adib Rifqi. (2020, April 3). Sharifah Halimah Alaydrus : a female preachers for our time. SocArXiv. DOI: https://doi.org/10.31235/osf.io/zb8qe

Setiawan, Adib Rifqi. (2020, April 2). Desain Pembelajaran untuk Membimbing Siswa Sekolah Dasar dalam Memperoleh Literasi Saintifik. EdArXiv. DOI: https://doi.org/10.35542/osf.io/u59f8

Setiawan, Adib Rifqi. (2020, April 2). What is the Best Way to Analyze Pre-Post Data?. EdArXiv. DOI: https://doi.org/10.35542/osf.io/h4e6q

Setiawan, Adib Rifqi. (2020, April 2). JUPE My Uncut Story. Open Science Framework (OSF). DOI: https://doi.org/10.31219/osf.io/qdxga

Setiawan, Adib Rifqi. (2020, April 1). Syarifah Halimah Alaydrus. Thesis Commons. DOI: https://doi.org/10.31237/osf.io/xbmcs

Setiawan, Adib Rifqi. (2020, April 1). Sharifah Halimah Alaydrus. Thesis Commons. DOI: https://doi.org/10.31237/osf.io/fp79c

Setiawan, Adib Rifqi. (2019, October 8). Biografi Clara Ng Perempuan Penulis Asal Indonesia. PsyArXiv. DOI: https://doi.org/10.31234/osf.io/yk8sx

Setiawan, Adib Rifqi. (2019, December 23). Contoh Langkah Pembelajaran Berorientasi Literasi Saintifik. santrimilenial.net. URL: https://santrimilenial.net/contoh-langkahpembelajaran-berorientasi-literasi-saintifik/

Setiawan, Adib Rifqi. (2019, June 14). Deasy Noviyanti, Perempuan Berbadan Defisit Lemak. qureta.com. URL: https://www.qureta.com/next/post/deasy-noviyanti-perempuanberbadan-defisit-lemak

Setiawan, Adib Rifqi. (2018, December 18). Irma Rahma Suwarma. qureta.com. URL: https://www.qureta.com/next/post/irma-rahma-suwarma

Setiawan, Adib Rifqi. (2018, October 05). Karen Armstrong. qureta.com. URL: https://www.qureta.com/next/post/karen-armstrong

Setiawan, Adib Rifqi. (2018, September 17). Lola Zieta Azelien. qureta.com. URL: https://www.qureta.com/next/post/lola-zieta-azelien 
Setiawan, Adib Rifqi. (2018, July 16). Rustriningsih, Srikandi Tersisih. qureta.com. URL: https://www.qureta.com/next/post/rustriningsih-srikandi-tersisih

Setiawan, Adib Rifqi. (2018, July 03). Tangis Daniela Hantuchová. qureta.com. URL: https://www.qureta.com/next/post/tangis-daniela-hantuchova

Setiawan, Adib Rifqi. (2018, June 28). Dewi Perssik. qureta.com. URL: https://www.qureta.com/next/post/dewi-perssik

Setiawan, Adib Rifqi. (2018, June 27). Ice. qureta.com. URL: https://www.qureta.com/next/post/ice

Setiawan, Adib Rifqi. (2018, May 24). Fakhrun. qureta.com. URL: https://www.qureta.com/next/post/fakhrun

Setiawan, Adib Rifqi. (2018, April 10). Eny Rochmawati Octaviani: memberikan hiburan, menyuntikkan harapan. Majalah SANTRI, 8: 15-18. URL: https://issuu.com/majalahsantri/docs/majalah_santri_8/17

Setiawan, Adib Rifqi. (2018, April 10). Busana: pemantas raga, pelaras jiwa. Majalah SANTRI, 8: 2627. URL: https://issuu.com/majalahsantri/docs/majalah_santri_8/28

Setiawan, Adib Rifqi. (2018, April 10). Rosa Amalia Iqony: paduan yakin diri dan rendah hati. Majalah SANTRI, 8: 46. URL: https://issuu.com/majalahsantri/docs/majalah_santri_8/48

Setiawan, Adib Rifqi. (2018, March 25). Novi Kaka: Sahabat, Panutan, Pembimbing. qureta.com. URL: https://www.qureta.com/next/post/novi-kaka-sahabat-panutan-pembimbing

Setiawan, Adib Rifqi. (2018, March 21). Bidadari di Kesunyian itu Bernama Maria Sharapova. qureta.com. URL: https://www.qureta.com/next/post/bidadari-di-kesunyian-itubernama-maria-sharapova

Setiawan, Adib Rifqi. (2018, March 19). Airin Rachmi Diany, Lilin Penerang Masyarakat Urban. qureta.com. URL: https://www.qureta.com/next/post/airin-rachmi-diany-lilinpenerang-masyarakat-urban

Setiawan, Adib Rifqi. (2018, March 19). Kamu dalam Aku: A Brief Story of Park Bom. qureta.com. URL: https://www.qureta.com/next/post/kamu-dalam-aku-a-brief-story-of-parkbom

Setiawan, Adib Rifqi. (2018, March 19). Guru yang Menyapih: Catatan Perjalanan Pribadi Nong Darol Mahmada. qureta.com. URL: https://www.qureta.com/next/post/guru-yangmenyapih-catatan-perjalanan-pribadi-nong-darol-mahmada

Setiawan, Adib Rifqi. (2018, March 17). Maryam Musfiroh: An Educator for Our Time. qureta.com. URL: https://www.qureta.com/next/post/maryam-musfiroh-an-educator-for-ourtime

Setiawan, Adib Rifqi. (2018, March 15). Eny R. Octaviani. qureta.com. URL: https://www.qureta.com/next/post/eny-r-octaviani

Setiawan, Adib Rifqi. (2018, March 14). Surely You're Joking, Mrs. Ilmy!. qureta.com. URL: https://www.qureta.com/next/post/surely-you-re-joking-mrs-ilmy

Setiawan, Adib Rifqi. (2018, March 14). Meniti Ilmuwati. qureta.com. URL: https://www.qureta.com/next/post/meniti-ilmuwati

Setiawan, Adib Rifqi. (2018, March 12). Clara Ng. qureta.com. URL: https://www.qureta.com/next/post/clara-ng

Setiawan, Adib Rifqi. (2018, March 11). Kisah Kasih Ayah di Balik Mata Najwa. qureta.com. URL: https://www.qureta.com/next/post/kisah-kasih-ayah-di-balik-mata-najwa 
Setiawan, Adib Rifqi. (2018, March 11). Rosa Amalia Iqony. qureta.com. URL:

https://www.qureta.com/next/post/rosa-amalia-iqony

Setiawan, Adib Rifqi. (2018, March 10). Venice Min. qureta.com. URL: https://www.qureta.com/next/post/venice-min

Setiawan, Adib Rifqi. (2018, March 09). Ketika YoonA Menyaksikan Real Madrid Menghempaskan PSG. qureta.com. URL: https://www.qureta.com/next/post/ketika-yoonamenyaksikan-real-madrid-menghempaskan-psg

Setiawan, Adib Rifqi. (2018, March 09). Kepedulian Airin Rachmi Diany pada Pendidikan. qureta.com. URL: https://www.qureta.com/next/post/kepedulian-airin-rachmidiany-pada-pendidikan

Setiawan, Adib Rifqi. (2018, March 09). Laila Fariha Zein (a.k.a. Uus atau Febi). qureta.com. URL: https://www.qureta.com/next/post/laila-fariha-zein-febi

Setiawan, Adib Rifqi. (2018, March 09). Pantat Perekat Umat. qureta.com. URL: https://www.qureta.com/next/post/pantat-perekat-umat

Setiawan, Adib Rifqi. (2018, March 09). Sisi Religi Grace Natalie. qureta.com. URL: https://www.qureta.com/next/post/sisi-religi-grace-natalie

Setiawan, Adib Rifqi. (2018, March 09). Asal Usul Nama Via Vallen. qureta.com. URL: https://www.qureta.com/next/post/asal-usul-nama-via-vallen

Setiawan, Adib Rifqi. (2018, March 07). Mengenal Oza Kioza. qureta.com. URL: https://www.qureta.com/next/post/mengenal-oza-kioza

Setiawan, Adib Rifqi. (2018, March 06). Menyoal Vokal Duo Serigala. qureta.com. URL: https://www.qureta.com/next/post/menyoal-vokal-duo-serigala

Setiawan, Adib Rifqi. (2018, March 06). Breast Capital. qureta.com. URL: https://www.qureta.com/next/post/breast-capital

Amatullah; \& Setiawan, Adib Rifqi. (2017, October 10). Nadirsyah Hosen: berkarya sebagai diaspora. Majalah SANTRI, 7: 56-59. URL:

https://issuu.com/majalahsantri/docs/santri_edisi_7/58

Setiawan, Adib Rifqi. (2017, June 03). Dari Yuli Hingga Julia. qureta.com. URL: https://www.qureta.com/next/post/dari-yuli-hingga-julia-2

Setiawan, Adib Rifqi. (2017, June 02). Aisha. qureta.com. URL: https://www.qureta.com/next/post/aisha-humaira

Setiawan, Adib Rifqi. (2015, November 10). Kehidupan Asmara Hawking: raga lumpuh, jiwa masih bisa tersentuh. fisikanet.lipi.go.id. URL:

http://www.fisikanet.lipi.go.id/utama.cgi?artikel\&1447145876\&2

Setiawan, Adib Rifqi. (2015, November 07). Dibalik Sampul Buku A Brief History of Time, agar pengetahuan tak hanya dinikmati ilmuwan. fisikanet.lipi.go.id. URL: http://www.fisikanet.lipi.go.id/utama.cgi?artikel\&1446855103\&2

Setiawan, Adib Rifqi. (2015, November 03). Dibalik Nama Besar Albert Einstein: Dari Politik, Asmara, hingga Matematika. fisikanet.lipi.go.id. URL: http://www.fisikanet.lipi.go.id/utama.cgi?artikel\&1446556354\&2

Setiawan, Adib Rifqi. (2015, October 31). Kurir Mikroskopis Alam Semesta bukan debu biasa. fisikanet.lipi.go.id. URL: http://www.fisikanet.lipi.go.id/utama.cgi?artike1\&1446304060\&2

Setiawan, Adib Rifqi. (2015, October 10). 10 Kejutan Subatomik. fisikanet.lipi.go.id. URL: http://www.fisikanet.lipi.go.id/utama.cgi?artikel\&1444577286\&3 